\title{
Collective Gratitude: Positive Organizational Scholarship Perspective
}

\author{
Büşra Müceldili ${ }^{1}$, Oya Erdil ${ }^{1}$, Ali Ekber Akgün ${ }^{1} \&$ Halit Keskin ${ }^{1}$ \\ ${ }^{1}$ Faculty of Business Administration, Gebze Technical University, Kocaeli, Turkey \\ Correspondence: Büşra Müceldili, Faculty of Business Administration, Gebze Technical University, Gebze, \\ Kocaeli, Turkey. Tel: 90-262-605-1413. E-mail: bmuceldili@gtu.edu.tr
}

Received: May 18, 2015

doi:10.5539/ibr.v8n8p92
Accepted: June 18, 2015

Online Published: July 25, 2015

URL: http://dx.doi.org/10.5539/ibr.v8n8p92

\begin{abstract}
This research examines collective gratitude, and makes three contributions to management literature. The first contribution is theoretical. The concept of gratitude is a vital emotion or a virtue for daily life in organizations. However, the collective effect of gratitude among employees in work place is interestingly missing in the organizational behavior literature. The second contribution is that we examine the collective gratitude in aspect of positive organizational scholarship. In this conceptual article we propose that contextual performance, team learning and high quality connection is enhanced by cultivating collective gratitude. The third contribution is of conceptual nature: provide a novel framework for future research.
\end{abstract}

Keywords: collective emotions, gratitude, high quality connections, positive organizational scholarship

\section{Introduction}

In recent years academic publications and popular press have given increasing attention to positive psychology. Gable and Haidt (2005, p. 104) defines positive psychology as "the study of the conditions and processes that contribute to the flourishing or optimal functioning of people, groups and institutions". Positive psychology focuses on strengthing and building the best and repairing the worst problems in life (Cameron et al., 2003) as well build positive qualities. It opens the way for flourishing and prospering to individuals, organizations and communities (Luthans \& Jensen, 2002). Positive psychology has three pillars; namely, positive subjective experiences, positive individual traits and positive institutions and organizations (Fineman, 2006). Positive experiences refer to past, present and future feelings; such as happiness, pleasure, joy, fulfillment and hope. Positive individual traits show the good characters such as wisdom, self esteem and courage. Lastly positive institutions or organizations where allows to enable positive experiences and traits in such as families, schools, business, communities and societies. After introducing positive psychology in 1998 by Seligman, much research has pointed to the importance of positive psychology, and is receiving broad attention in a variety of disciplines such as education, public health, human services, health care, political science, neuroscience, economics, leadership, management and the organizational sciences (Donaldson \& Ko, 2010).

In organizational behavior and theory; there have been two recent movements or fields which have built on positive psychology; positive organizational behavior (POB) and positive organizational scholarship (POS). Both of these fields share the common root of positive psychology (Donaldson \& Ko, 2010) and have attracted considerable attention in organizational studies. Although in the literature POB and POS are used interchangeably, they have distinct meanings and characteristics (Donaldson \& Ko, 2010). Firstly POB is concerned with temporary or state-like characteristics whereas; POS is concerned with stable or trait-like qualities (Wright \& Quick, 2009). While POB refers to "the study and application of positively oriented human resource strengths and psychology capacities that can be measured, developed and effectively managed for performance improvement in today's work place (Luthans, 2002, p. 59); POS is "concerned primarily with the study of especially positive outcomes, processes, and attributes of organizations and their members" (Cameron et al., 2003, p. 4). Secondly, POB emphasizes the criterion of being related to performance, POS highlights positive constructs such as compassion, gratitude, virtue for flourishing today's organizations. Lastly, the difference among POS and POB exists in the level of analysis. While POB emphasizes micro level of analyses of organizations (individuals); POS focuses on macro level of analyses of organizations (organization).

POS can be accepted as the organizational equivalent of positive psychology (Cameron et al., 2003) and focuses on macro levels of analysis in organizations. In the concept of POS, "positive" refers to an affirmative side in 
organizations; "organizational" refers to the process and dynamics in and through organizations, lastly "scholarship" refers to empirically research and theoretically scientific qualitative and quantitative method side which is cornerstone of POS (Caza \& Caza, 2008). POS provides a positive lens for seeing, analyzing and understanding organizations. Several positive scholars focus on the possibilities for the best that organizations can become rather than identifying and overcoming problems (Roberts, 2006).

In their major study Cameron et al. (2004) point out that POS is an umbrella of diverse set of theories and topics which indicate affirmative, uplifting and elevating process and outcomes. Positive concepts such as virtues, character strength, authentic leadership, resilience, transcendence, empowerment, appreciative inquiry, energy, meaningfulness and gratitude take part in the positive umbrella. After the positive concepts were first introduced, they have received considerable interest in organizational studies through the constructs such as optimism, which is linked with job related outcomes (Kluemper et al., 2009), happiness which is associated with affective commitment (Rego et al., 2011) and organizational citizenship behavior (Rego et al., 2010) and virtuous acts such as optimism, trust, compassion, trust, integrity forgiveness which are linked with perceived organizational performance (Cameron et al., 2004).

The emergence of positive perspective in organizations (i.e. positive organizational scholarship) has brought new attention to gratitude. Gratitude is one of the important components of POS umbrella and provides to flourish and prospers organization members in extraordinary ways. Following Emmons's recommendations (2003) this study responds to this call and investigates gratitude and offer insights into how gratitude at work contribute to a deeper understanding of POS. This study makes important contributions to positive organizational scholarship. First, the study gives attention to one of the discrete emotion which is listed by Lazarus and Cohen's 15 discrete emotions for understanding the role of emotions in particular organizational context and investigating the outcomes which gratitude produce at work. Second, the study provides collective gratitude concept. To our knowledge, no research has explored the collective gratitude as an emotional state in organizational functioning. Lastly, positive organizational scholars have called more research investigating gratitude in work (Emmons, 2003; Cameron et al., 2004). This research answers this call and investigates collective gratitude in organizational context.

The purpose of this conceptual paper is to emphasize the importance of positive emotion-gratitude- at work. We develop logical and complete arguments and propose new relationships among constructs rather than testing them empirically (Gilson \& Goldberg, 2015). We review theoretical and empirical evidence on the unique characteristics of gratitude from general positive organizational scholarship perspective, linking this evidence to the macro organizational context and propose the consequences of collective gratitude in the organizations. We organize this article around four sections. In the first section, literature review is provided. We define gratitude and collective gratitude and specifically review prior work on gratitude. In the second section we discuss the consequences of collective gratitude. As a conceptual paper we offer previously untested relationships among variables. Finally, the last section provides discussion and guidelines for future researches.

\section{Literature Review}

\subsection{Gratitude: An Overview}

In the Oxford English Dictionary gratitude is defined as "the quality or condition of being thankful; the appreciation of an inclination to return kindness". According to Oxford English Dictionary gratitude comes from the Latin word gratia, meaning grace, graciousness, gratefulness and gratia implies "kindness, generousness, gifts and the beauty of giving and receiving". Gratitude refers felt of sense of wonder, thankfulness and appreciation for life (Emmons, 2003). Accordingly, gratitude have three components; a benefactor, benefice and a beneficiary. Gratitude occurs when beneficiary realize the value of gift (benefice) and the intention of the benefactor. Benefits can be tangible or intangible goods, psychological or emotional nature (McCullough et al., 2001). Emmons et al. (2003) state gratitude can be both personal and transpersonal. While personal gratitude refers to thankfulness toward a specific person for example, family, friend, colleagues or boss, transpersonal gratitude refers to thankfulness to God, nature or cosmos.

Gratitude has very long intellectual and moral histories hence has been defined in many ways by philosophers and psychologists. In order to identify the previous literature on the gratitude we carried out a literature review (see Table 1). For example, Kant defines gratitude as (1797) "honoring a person because of kindness he has done us" (Emmons, 2003; Kant, 1797, p. 5). Brown (1820) defines gratitude as "that delightful emotion of love to him who has conferred a kindness he has done us" (Emmons, 2003; Brown, 1820, p. 5).

According to moral philosophers gratitude is accepted the parent of all others' virtues. Virtue defined as a character that allows a person to think and to act for benefit him/herself and society (Chun, 2005; Shryack et al., 
2010). Park and Peterson (2003) argue that gratitude is in VIA (virtue in action) classification and classified in the virtues of transcendence, spirituality, appreciation of beauty, hope and humor that are comprised of strengths that provide meaning for the individual and provide the link with the universe. In accordance with this perspective gratitude is defined as "being aware of and thankful for the good things that happen" (Park \& Peterson, 2003, p. 36).

Additionally gratitude is a universally esteemed virtue in world religions, including Judaism, Christianity and Islam. Judaism highlights the importance of thanking God since ancient Israel. In a similar vein, Christianity obliges Christians to thank to the source of their lives. Moreover individuals tend to show their appreciation in different context. For example in United States Thanksgiving day is celebrated for showing gratefulness. In Islam, in the Koran, the necessity and powerless of gratitude and thankfulness to God is emphasized.

According to Fredrickson (2004) and Smith and Ellsworth (1985) gratitude is conceptualized as a temporary emotional state. Gratitude is classified as positive emotion, moral emotion, emphatic emotion and social emotion. Since gratitude has a positive valence (Emmons et al., 2003), it can be classified in positive emotions like, joy, interest, contentment, love and pride. However gratitude has a unique place in these positive emotions. McCullough et al. (2002) remark the uniqueness of gratitude in their study through experimental studies. The results of the study show that gratitude is related but distinct from other positive emotions through its unique functions such as prosocial behavior and altruism. Moreover, McCullough et al. (2001) state that gratitude has three moral functions namely; moral barometer function, moral motive function and moral reinforcement function. Moral barometer function indicates the readout of beneficiary in the case of receiving intentional benefit from benefactor. Moral motive function points out extension of reciprocity and how people respond benefactors. For example grateful individuals search to repay kindness in many ways. Lastly, moral reinforcement function highlights how gratitude encourages to acts prosocial behavior among individuals in the future.

Lazarus and Lazarus (1994) state that gratitude is an emphatic (other oriented) emotion. In a similar vein, Grant and Wrzesniewski (2010) argue anticipated gratitude with regard to other-oriented emotion. Other-oriented indicates concern for the thoughts of other people. For example, anticipated gratitude shows expectation others for their contributions.

As a social emotion gratitude is defined as one of the primary motivators of benevolent behavior toward a benefactor by Adam Smith (1976) (Emmons, 2003). According to Smith, gratitude is the sentiment which most immediately and directly prompts individuals to reward. In other words, if an individual have recognized or appreciated the gift or any benevolent behavior from benefactor, he/she wants to search new ways to respond the benevolence.

While gratitude is investigated as an emotion the distinction among state and trait gratitude is crucial. Gratitude is conceptualized both state and trait in the literature (Watkins et al., 2009). State gratitude is related to recognition of the benefit. Emmons (2003) and McCulluogh et al. (2001) suggested and empirically showed that individuals feel positive emotional reaction when they gain a benefit from benefactor or appreciation of good things enhances state gratitude (Watkins et al., 2009). While state gratitude captures the gratitude that may change based on contextual factors, trait gratitude symbolize generally experienced gratitude. Trait gratitude represents dispositional tendency of positive things in life. Fitzgerald (1998) explained trait gratitude via three components; namely; (i) a warm sense of appreciation for somebody or something, (ii) a sense of goodwill toward that person or thing, (iii) a disposition to act that flows from appreciation and goodwill. With respect to trait gratitude, Emmons (2003) argues that trait gratitude have four facets. The first facet is intensity and refers to one's strong grateful disposition. The second facet is frequency and indicates to one's gratefulness per time. The third facet is span and implies one's grateful circumstances in their life for example health, family, etc... The last facet is density and shows the number of grateful things in life i.e. one thing or a list of grateful things.

Further, according to Raggio et al. (2014) gratitude can be investigated via three major categories of contributors "cognitive, emotional and behavioral". Cognitive component showcase mental process in perceiving and recognition of benefit. Emotional component points out appreciation of benefit. Finally behavioral component, which demonstrates observable elements of gratitude, indicates acknowledgment of benefit.

\subsection{Conceptualizing of Collective Gratitude}

In daily life the imperative role of gratitude to people is shown by researches (Watkins et al., 2003). According to a research, which was applied to American and German adults, gratitude is a useful and constructive emotion. Furthermore, $10 \%$ and $30 \%$ of individuals felt the emotion of gratitude regularly and often (McCullough et al., 2001). As the organizations are composed of people, it is expected that gratitude will be important for 
organizations too. Indeed gratitude exists in the work environment and highly important for workplace behavior. Although gratitude is conceptualized and defined as a moral virtue, an attitude, an emotion, a habit, a personality trait and a coping response (Lambert et al., 2009) at individual level, it remains incapable to explain gratitude as an organizational phenomenon. As shown in Table 1, each of the studies investigates consequences of gratitude and suggests implications for future empirical research. Further, there are now a limited number of studies in diverse areas of management of gratitude and collective gratitude.

Furthermore, in the literature review we discover that positive emotions in organizations frequently studied solely an individual-level phenomenon. However, workplaces are the places where individuals face to homogenous situational factors that individuals reacts collective response tendencies and shared interpretations (Cole et al., 2012).

For the reasons that inadequateness, we follow Bandura (1997) and Walumbwa et al. (2009) and transitioned personal gratitude to collective gratitude. From this perspective we defined collective gratitude the "group's shared positive emotional state recognizing and being thankful for the good things happen". To identify collective gratitude concept we use two theoretical perspectives including affective events theory, intergroup emotion theory (Muller et al., 2014; Akgün et al., 2015). Affective events theory shows that the variation of the features and perceptions of affective events (Weiss \& Cropanzona, 1996) and intergroup emotion theory reflects the spread of emotions through interactions among organizational members experiencing (Barsade, 2002). Collective gratitude is likely to be important for helping groups to recognize and appreciate organizational benefits. Indeed, group-level gratitude may often be more effective than individual-feelings of gratitude. According to Fredrickson (2001) broad and build theory collective gratitude produces function at higher levels beside, individuals function at higher levels.

\section{Consequences of Collective Gratitude}

Gratitude seems necessity for today's extremely changing employment conditions. Today's employees are more mobile, more autonomous and less dependent on their organizations than ever before (Grant et al., 2008). In this sense, collective gratitude can be a key element in the organizations to procure positive organizational outcomes.

Gratitude can help eliminating the toxic workplace emotions, attitudes and negative emotions such as envy, anger and greed in today's highly competitive work environment. Envy originates from ingratitude and research in the envy literature has found that envy predicts negative outcomes, including counterproductive work behaviors (Khan et al., 2014), moral disengagement (Duffy et al., 2012) and social undermining, poor mental health and depressive tendencies (Tai et al., 2012). Contrary to envy, gratitude prompts more physical and emotional health (Emmons \& Shelton, 2002). For example, Maslow emphasizes the role of experience and express gratitude for emotional health (Emmons \& Shelton, 2002). As a positive emotion, gratitude has a unique capacity to down-regulate negative emotions' unhealthy results which arouse people's autonomic nervous systems, producing increases in heart rate, vasoconstriction and blood pressure (Fredrickson, 2003). Due to physical and mental health are reciprocally linked, gratitude leads to more healthy employees. According to Goetzel et al. (2001) more than fifty percent of the total costs associated with poor health. This healthy and satisfying individuals may perform positive contribution to his or her organization such as employee happiness and well being that are positively related with performance, commitment in contrast the result of envy such as absenteeism, sabotage, theft and other deviant workplace behaviors (Emmons, 2003). Additionally, gratitude not only eliminates the toxic workplace emotions, but also provides strength and harmony (Fredrickson, 2004) through binding people together in organizations. Since emotions are contagious, each person's gratitude experiences can reverberate through others and gratitude spreads through groups and then organizations. While gratitude builds bonds of harmony and community in organizations, ingratitude disrupts harmony. Building our conceptualization of collective gratitude as a positive emotion, we address the consequences of gratitude for organizations. We propose a basic model (Figure 1) to explain these positive consequences.

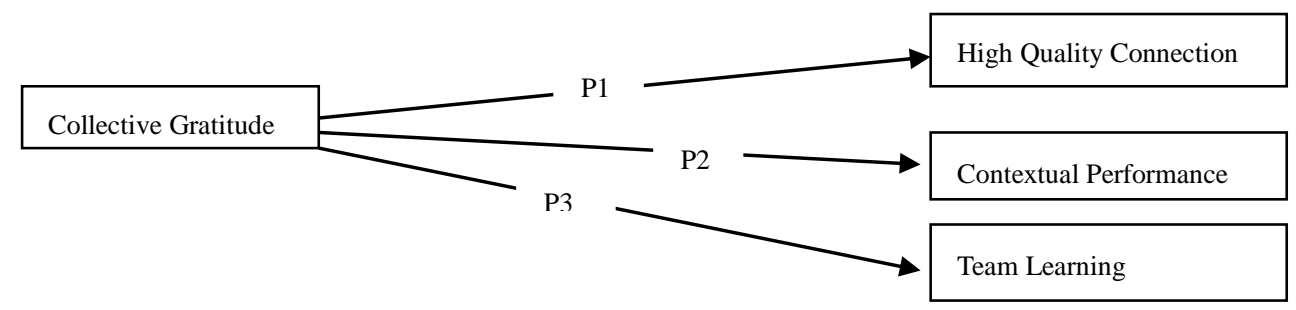

Figure 1. Proposed model 
Table 1. The conceptualization of gratitude in the literature

\begin{tabular}{|c|c|c|c|c|c|c|}
\hline Author & Conceptual definition of gratitude & $\begin{array}{l}\text { Operatio } \\
\text { nal } \\
\text { definition }\end{array}$ & \multicolumn{2}{|l|}{ Summary } & $/ \mathrm{C}$ & Distinet Characteristics \\
\hline $\begin{array}{l}\text { Adam Smith (1790/1976 } \\
\text { cf. MoCullough,2001)) }\end{array}$ & $\begin{array}{l}\text { Gratitude is one of the most basic social } \\
\text { emotion and is one of the primary motivators } \\
\text { of benevolent behavior toward a benefactor. }\end{array}$ & & \multicolumn{3}{|c|}{$\begin{array}{l}\text { Identified the meaning and importance of gratitude for } \\
\text { society, and explained gratitude role for promoting } \\
\text { social stability. According to Smith, beneficiaries feel } \\
\text { and express gratitude toward benefactors who, intend } \\
\text { to benefit them, succeed in beneffiting them and are } \\
\text { capable of sympathizing with the beneficiary's grateful } \\
\text { feelings. }\end{array}$} & Social moral emotion \\
\hline $\begin{array}{l}\text { Simmel (1950cf. } \\
\text { McCullough,2001) }\end{array}$ & $\begin{array}{l}\text { Gratitude can be defined as the moral memory } \\
\text { of mankind }\end{array}$ & & & & & Moral emotion \\
\hline Tesser (1968) & $\begin{array}{l}\text { Gratitude are a function of the recipient's } \\
\text { perception of the intention of the benefactor, } \\
\text { the cost to the benefactor in providing the } \\
\text { benefit and the value of benefit }\end{array}$ & & \multicolumn{3}{|c|}{$\begin{array}{l}\text { The study empirically tests the gratitude. The study test } \\
\text { the determinants of gratitude by using qualitative } \\
\text { method via story telling: Stories were given to groups } \\
\text { of undergraduate males. The results imply that the } \\
\text { mathematical model is supported and gratitude is } \\
\text { associated with perceived altruism, cost and value. }\end{array}$} & $\begin{array}{l}\text { Emphasize moral aspects of } \\
\text { gratitude }\end{array}$ \\
\hline Berger(1975) & & & \multicolumn{3}{|c|}{$\begin{array}{l}\text { The study explains the features of gratitude. Gratitude } \\
\text { strengths the bonds of moral community and plays a } \\
\text { role in interrelationships because gratitude involves the } \\
\text { demonstration of our feelings toward another. } \\
\text { Involving reciprocation differs gratitude from other } \\
\text { disciplines }\end{array}$} & \\
\hline Fitzgerald (1998) & $\begin{array}{l}\text { Gratitude is an emotion or set of feelings. } \\
\text { Gratitude has three components. Gratitude is a } \\
\text { warm sense of appreciation for sb or sth, a } \\
\text { sense of goodwill toward that individual or } \\
\text { thing, a disposition to act which flows from } \\
\text { appreciation and goodwill. }\end{array}$ & & \multicolumn{3}{|c|}{$\begin{array}{l}\text { This study classifies the grateful situations via } \\
\text { examples from the daily lives. Gratitude to those who } \\
\text { harm you, gratitude to someone whom you benefit, } \\
\text { unwarranted gratitude, and gratitude simply is a } \\
\text { response to benefit or favor. }\end{array}$} & An emotion or set of feelings \\
\hline $\begin{array}{l}\text { McCullough et. al. } \\
\text { (2002) }\end{array}$ & $\begin{array}{l}\text { Gratitude is a felt sense of wonder, } \\
\text { thankfulness and appreciation for benefits } \\
\text { received. Gratitude can be given } \\
\text { interpersonally or transpersonally }\end{array}$ & \multicolumn{2}{|c|}{$\begin{array}{l}\text { Having so much in life to be thankful for, having } \\
\text { a long list grateful for, grateful to a wide variety } \\
\text { of people, appreciating the people, events }\end{array}$} & $\begin{array}{l}\text { This study defines the } \\
\text { grateful disposition } \\
\text { through four facets; } \\
\text { gratitude intensity, } \\
\text { gratitude density, gratitude } \\
\text { frequency and gratitude } \\
\text { span. The authors also } \\
\text { investigate gratitude } \\
\text { functions another major } \\
\text { study (2001) and they }\end{array}$ & $\begin{array}{l}\text { C/ subjective } \\
\text { well-being. } \\
\text { health. }\end{array}$ & $\begin{array}{l}\text { Affective trait, } \mathrm{GQ} \text { is an } \\
\text { unidimensional scale. }\end{array}$ \\
\hline Watkins et al. (2003) & $\begin{array}{l}\text { Grateful affect is a feeling of thankful } \\
\text { appreciation for favors received and trait } \\
\text { gratitude would be the predisposition to } \\
\text { experience this state. }\end{array}$ & \multicolumn{2}{|c|}{$\begin{array}{l}\text { Not feeling deprived in life, being appreciative } \\
\text { of the contribution of others to their well-being, } \\
\text { they have tendency to appreciate simple } \\
\text { pleasures, acknowledging the importance of } \\
\text { expressing and experiencing gratitude. }\end{array}$} & $\begin{array}{l}\text { This study developed a } \\
\text { Gratitude, Resentment and } \\
\text { Appreciation Test } \\
\text { (GRAT). In the GRAT, } \\
\text { gratitude involves; } \\
\text { appreciation of people, } \\
\text { appreciation of life and the } \\
\text { absence of feelings of } \\
\text { deprivation. }\end{array}$ & $\mathrm{C} /$ Happiness & Trait gratitude, GRAT scale \\
\hline Adler \& Fagley (2005) & \multirow[t]{2}{*}{$\begin{array}{l}\text { Gratitude is conceptualized as aspect of } \\
\text { appreciation and refers to noticing and } \\
\text { acknowledging a benefit that has been received } \\
\text { a person or transperson. Noticing the sacrifices } \\
\text { and expressing the appreciation }\end{array}$} & & & $\begin{array}{l}\text { This study developed a } \\
\text { scale for appreciation and } \\
\text { gratitude is a component } \\
\text { of appreciation with have } \\
\text { focus, awe, ritual, present } \\
\text { moment, self/social } \\
\text { comparison, } \\
\text { loss/adversity and } \\
\text { interpersonal. }\end{array}$ & $\begin{array}{l}\mathrm{C} / \text { well-being } \\
\text { and life } \\
\text { satisfaction }\end{array}$ & $\begin{array}{l}\text { Positive emotional reaction. } \\
\text { Gratitude is one dimension } \\
\text { of The Appreciation Scale }\end{array}$ \\
\hline Palmatier (2009) & & $\begin{array}{l}\text { Feeling gratefu } \\
\text { motives the rec } \\
\text { compliance wit }\end{array}$ & $\begin{array}{l}\text { to benevolence from another, } \\
\text { ipient to reward the giver and } \\
\text { h any subsequent requests. }\end{array}$ & $\begin{array}{l}\text { This study emphasized the } \\
\text { role of customer gratitude } \\
\text { in relationship marketing. } \\
\text { Data is gathered from a } \\
\text { laboratory experiment }\end{array}$ & $\begin{array}{l}\text { C/ customer' } \\
\text { purchase } \\
\text { intention and } \\
\text { seller } \\
\text { performance }\end{array}$ & Emotional core of reciprocity \\
\hline Park\&Peterson (2003) & $\begin{array}{l}\text { Gratitude is a transcendence virtue that forges } \\
\text { connections to the larger universe and provide } \\
\text { meaning. Transcendent virtues, those inner } \\
\text { qualities that strengthen bonds and connections } \\
\text { with entities beyond the self. Gratitude is a } \\
\text { being aware of and thankful for the good things } \\
\text { that happen; taking time to express thanks }\end{array}$ & Feeling and $\mathrm{ex}_{\mathrm{f}}$ & ressing the gratitude & $\begin{array}{l}\text { This study classifies } \\
\text { virtues as wisdom, } \\
\text { courage, humanity, justice, } \\
\text { temperance, transecendence } \\
\text { and these six core virtues } \\
\text { includes twenty -four } \\
\text { positive trait. }\end{array}$ & $\begin{array}{l}\text { C/Organizatio } \\
\text { nal } \\
\text { Performance }\end{array}$ & $\begin{array}{l}\text { Gratitude is one of the a } \\
\text { positive trait in } \\
\text { transcendence virtue }\end{array}$ \\
\hline Froh (2011) & $\begin{array}{l}\text { Gratitude is the appreciation experienced by } \\
\text { individuals when somebody does something } \\
\text { kind or helpful for them. }\end{array}$ & & & $\begin{array}{l}\text { This study measures } \\
\text { gratitude in youth through } \\
\text { GQ6, GAC, GRAT scales } \\
\text { that is used assessing the } \\
\text { psychometric properties of } \\
\text { adult gratitude. }\end{array}$ & $\begin{array}{l}\text { C/Positive } \\
\text { affect and life } \\
\text { satisfaction }\end{array}$ & $\begin{array}{l}\text { Gratitude is a cognitively } \\
\text { complex emotion with } \\
\text { specific social-cognitive } \\
\text { appraisals. }\end{array}$ \\
\hline Tsang et al.(2012) & $\begin{array}{l}\text { Gratitude is a positive emotional reaction to the } \\
\text { receipt of a benefit that is perceived to have } \\
\text { resulted from the good intentions of another }\end{array}$ & & & $\begin{array}{l}\text { This study measures } \\
\text { gratitude through } \\
\text { laboratory experiment by } \\
\text { self report and } \\
\text { investigated the } \\
\text { relationship between } \\
\text { gratitude and religion. }\end{array}$ & & State gratitude \\
\hline Grant (2010) & $\begin{array}{l}\text { Anticipated gratitude is a promotion-focused } \\
\text { emotional state that is typically elicited when } \\
\text { employees think about work-related success } \\
\text { and motivates employees to take action to } \\
\text { facilitate feelings of gratitude in others. }\end{array}$ & & & $\begin{array}{l}\text { This study measures } \\
\text { gratitude in terms of the } \\
\text { prosocial motivation or the } \\
\text { desire to benefit others. }\end{array}$ & & \\
\hline
\end{tabular}




\subsection{Relationship with High Quality Connection (HQC)}

Organizations are composed of individuals who interact with each other's naturally. Just as daily life in work life individuals have to contact and connect each other for functional purposes (goal attainment) and satisfying basic human psychological needs (autonomy, competence and relatedness) (Fernet et al., 2010). The quality of the connection is critical at work, it is essential for organization's energy, well-being and performance (Dutton, 2003). The power of high quality connection is felt and sensed for the organizations. HQC have momentous consequences for both individuals and organizations. While HQC increases the energy, detecting errors, engaging in generalized learning behaviors (Brueller \& Carmeli, 2011); corrosive connections absorb all energy at work and give back nothing (Dutton, 2003). Low quality connection damages employees' capability, knowledge, motivation, commitment, and emotional reserves (Dutton, 2003). Dutton (2003) lists benefits of HQC for individuals and organizations. For individuals HQC facilitates physical and psychological health, enable individuals to engage more fully in the tasks that compose their job, enable to learn more easily; for organizations HQC enhances the capacity to cooperate within and across units, facilitates effective coordination between interdependent parts of an organization, increase employees' attachments to their organizations, expedite organizational learning, help to transfer organizational culture and provides support to change and adapt. For this important reason, positive organizational scholars focus HQC and strive the understanding the power of HQCs to explain extraordinary experiences and performance. HQCs can be short interactions or long-term relationships. According to Stephens et al. (2012) HQC refers to short-term, dyadic positive interactions at work. HQCs are ties between two or more individuals that are marked by both positive structural features (emotional carrying capacity which indicates the expression both positive and negative emotions in the connection; connect it which indicates generativity and openness to new ideas and influences, and help to change behaviors that destroy generative process; and senility which indicates connection capability for withstanding strain in a variety of circumstances (Raggins \& Dutton, 2007) and positive subjective experiences (vitality, mutuality and positive regard) (Brueller \& Carmeli, 2011).

Furthermore, there are three sets of mechanism which use for explaining high-quality connections; namely are, cognitive, emotional and behavioral (Stephens et al., 2012). All of the mechanism emphasized the role of gratitude. The pivotal role of gratitude in promoting positive social relationships has been suggested by philosophers and scientists for centuries. There are evidences in the literature which show the link between relationship quality and gratitude. As an emotion gratitude facilitates and strengthens relationships (Barlett et al., 2012). In the cognitive mechanism perspective taking dimension foster interpersonal virtues, such as gratitude (Williams, 2012). Perspective taking enables employees to understand the intentions of their benefactor and recognize the value of the gift from the benefactors' point of view (Williams, 2012). In the emotional mechanism perspective positive emotions dimension is important for building HQCs. Positive emotions-especially gratitude-is relevant for building HQCs. Gratitude experiences lead to greater connections over time (Stephens et al., 2012). And lastly, behavioral mechanism's dimensions respectful engagement and task enabling facilitate the building of HQCs with gratitude. The link between respectful engagement, task enabling and gratitude increases connection quality (Stephens et al., 2012).

Proposition 1: A positive relationship exists between collective gratitude and high quality connection.

\subsection{Relationship with Contextual Performance}

We also argue that collective gratitude promotes helping behaviors, extra-role behavior (i.e. contextual performance) by advancing helping and compassionate behaviors in organizations. Contextual performance is different from task performance. While task performance focuses on performing job requirements, contextual performance indicates volunteering to perform task activities beyond formally part of the job for example helping and cooperating with others to accomplish organizational goals. The term contextual performance has attracted many researchers and tackles social, psychological and organizational contexts (Borman \& Motowidlo, 1997). However, scholars emphasize the role of individual differences, attitudinal variables and leadership factors (Podsakoff et al., 2014) give less attention to the role of collective emotions.

Collective gratitude enhances the positive consequences of contextual performance by emphasizing the importance of reciprocity (Algoe et al., 2008). For example giving opportunity for promotion or extra reward can build gratitude and facilitate extra-role performance. When organizational members show prosocial behaviors especially toward helpers who have provide benefit them previously, gratitude experiences have aroused. In addition, collective gratitude enhances to develop a shared understanding and recognizing benefit and means to repay kindness and go beyond their core tasks.

Collective gratitude also increases contextual-performance by facilitating the team communication. Through 
collective gratitude cohesion and commitment increases and all cohesion and commitment promote helping others in networks (Baker, 2012). Collective gratitude prompts employees to actively engage interpersonal relationships and mutually understand each other and motives that drive contextual performance. Collective gratitude facilitates to emerge contextual performance as well enhances its continuance. Sekerka et al. (2012) indicate reciprocal nature of gratitude and feelings of give back.

Proposition 2: A positive relationship exists between collective gratitude and contextual performance.

\subsection{Relationship with Team Learning}

Collective gratitude through emotional contagion spreads from one employee to the next (Barsade, 2002) and contributes to the sharing of knowledge. We suggest that collective gratitude positively drives team learning through social bonds. Social bonds leverage reliable relationship (Akgun et al., 2015) and increase employee voice (Hu \& Kaplan, 2014), that foster team learning (Carmeli et al., 2009). Collective gratitude also enhances team learning by leveraging team members' appreciation. When team members are promoted participative decision making or declare opinion freely will be appreciative and donate their time and knowledge for the team members. In addition, collective gratitude foster positive emotions (Emmons, 2003). Positive emotions leverage upward spiral and broadening team members thinking and action which provides transmission and integration of knowledge among team members. Moreover collective gratitude provides a cooperative culture (Hu and Kaplan, 2015) and encourages learning within and between organizations. With regard to Lazarus (1991) gratitude is an empathic emotion and leads to improve learning efforts in team working (Akgün et al., 2015).

Proposition 3: A positive relationship exists between collective gratitude and team learning.

\section{Discussion}

Our conceptual model of collective gratitude provides new perspectives for positive organizational scholars. We propose that collective gratitude is a state-like positive emotion characterized by thankfulness at beneficiary's benefits. By highlighting the role of collective gratitude, this study provides a framework for researchers and managers to visualize and understand the relationship between collective positive emotions and positive organizational outcomes.

\subsection{Theoretical and Practical Implications}

As a conceptual paper, the study address to take a problem focused approach and what's new question thoroughly (Gilson \& Goldberg, 2015) and provides to link across disciplines and enable to broad insights. To address, we underscore the importance of collective gratitude in a deeply manner. We respond to a call from organizational researchers for understanding of collective emotions (Huy, 2012). The current study takes the idea further and indicates collective gratitude in organizational research perspective.

As a positive emotion gratitude underscores in marketing for example in their study Romani et al. (2013) and Raggio et al. (2014) discussed the influence of customer gratitude on social responsibility and relationship marketing in individual level, however the studies in organizational behavior and theory is nascent. Notwithstanding the possibility of employee gratitude in organizations has been theorized (Hu \& Kaplan, 2015; Emmons, 2003), the present research is the first to give collective perspective to these ideas and the study leads to understanding the role of collective gratitude in organizational level. Although individual level and collective level gratitude share some similarities, they are not similar in structure. Specifically through this study we emphasized the role of affective events theory and intergroup emotion theory. Both of the theories shed light on the collective role of emotions for gaining positive outcomes.

Whereas our research focuses on psychological aspects of gratitude, we see the potential for cardiovascular work related health. Positive emotions at work can build physical health and this helps to establish organizational effectiveness. For instance, Wright and Diamond (2006) emphasized the relationship among cardiovascular and individual efficiency and organizational effectiveness.

Beside theoretical contribution our research has value for practitioners (i.e., managers, organizations and stakeholders). First, it can contribute to reduce turnover intention. Recognition of the rewards or organizational inducements fosters employees' organizational commitment. From this research management can understand the role of emotions to gain positive organizational outcomes.

Further management should consider that collective gratitude is important for building connections among employees and enhancing energy and life-depleting, vital organizations. In this respect, collective gratitude promotes meaning and calling for work.

Lastly, management should organize extra training and development programs for cultivating gratitude. This way, 
employees feel that the firm cares about their welfare.

\subsection{Limitations and Future Research}

This study proposed that collective gratitude is related to high quality connections, team learning and contextual performance. It would be useful to empirically illustrate the impact of collective gratitude on organizational outcomes. Moreover, the moderating effects of positive psychological capital (PsyCap) can be investigated the relationship among collective gratitude and contextual performance.

Furthermore, we also note that measuring the impact of collective gratitude need to be evaluated within more sophisticated research designs such as diary studies for providing deepen understanding of the antecedents and consequences of collective gratitude. For instance, an employee in a firm gain a reward is more likely to perceive gratitude than an employee in a firm with no appreciation. Likewise, the frequency of reward is likely to influence perceived gratitude.

Here, we specifically showed the consequences of collective gratitude. Future researches can investigate antecedents of collective gratitude. For instance, authentic leadership, organizational culture and organizational justice should be helpful in identifying or conceptualizing collective gratitude.

In this study, we argued positive aspects of collective gratitude, however as Lindebaum and Jordan (2012) states that positive emotions can lead to negative consequences. In this sense, the negative outcomes of collective gratitude can be investigated.

\section{Conclusion}

The aim of the study was to present an overview of gratitude and indicate its relevance to the realm of work and organizations. To better understand gratitude as applied at work, we presented collective conceptualization of gratitude and relationship among organizational outcomes.

\section{References}

Adler, M. G., \& Fagley, N. S. (2005). Appreciation: Individual differences in finding value and meaning as a unique predictor of subjective well-being. Journal of Personality, 73(1), 79-114. http://dx.doi.org/10.1111/j.1467-6494.2004.00305.x

Akgun, A. E., Keskin, H., Cebecioglu, A. Y., \& Dogan, D. (2015). Antecedents and consequences of collective empathy in software development project teams. Information \& Management, 52(2), 247-259. http://dx.doi.org/10.1016/j.im.2014.11.004

Algoe, S. B., Haidt, J., \& Gable, S. L. (2008). Beyond reciprocity: Gratitude and relationships in everyday life. Emotion, 8(3), 425-429. http://dx.doi.org/10.1037/1528-3542.8.3.425

Baker, W. (2012). A dual model of reciprocity in organizations: Moral Sentiments and Reputation. In K. S. Cameron, \& S. Gretchen (Eds.), The Oxford handbook of positive organizational scholarship (pp. 412-422). New York: Oxford University Press.

Bandura, A. (1997). Self-efficacy: The exercise of control. New York: Freeman.

Barlett, M., Condon, P., Cruz, J., Bauman, J., \& Destono, D. (2012). Gratitude: Prompting behaviors that build relationships. Cognition \& Emotion, 26(1), 2-13. http://dx.doi.org/10.1080/02699931.2011.561297

Barsade, S. G. (2002). The ripple effect: The emotional contagion and its influence on group behavior. Administrative Science Quarterly, 47(4), 644-675. http://dx.doi.org/10.2307/3094912

Berger, F. R. (1975). Gratitude. Ethics, 85(4), 298-309. http://dx.doi.org/10.1086/291969

Borman, W. C., \& Motowidlo, S. J. (1997). Task performance and contextual performance: The meaning for personnel selection research. Human Performance, 10(2), 99-109. http://dx.doi.org/10.1207/s15327043hup

Brueller, D., \& Carmeli, A. (2011). Linking capacities of high quality relationships to team learning and performance in service organizations. Human Resource Management, 50(4), 455-477. http://dx.doi.org/10.1002/hrm.20435

Cameron, K. S., Bright, D., \& Caza, A. (2004). Exploring the relationships between organizational virtuousness $\begin{array}{lllll}\text { and } & \text { American }\end{array}$ http://dx.doi.org/10.1177/0002764203260209

Cameron, K. S., Dutton, J. E., \& Quinn, R. E. (2003). Foundations of positive organizational scholarship. In K. S. Cameron, J. E. Dutton, \& R. E. Quinn, (Eds.), Positive organizational scholarship: Foundations of a new discipline (pp. 3-13). San Francisco: Berrett-Koehler Publishers. 
Caza, B. B., \& Caza, A. (2008). Positive organizational scholarship: A critical theory perspective. Journal of Management Inquiry, 17(1), 21-33. http://dx.doi.org/ 10.1177/1056492607305907

Chun, R. (2005). Ethical character and virtue of organizations: An empirical assessment and strategic implications. Journal of Business Ethics, 57,269-284. http://dx.doi.org/ 10.1007/si 0551-004-6591-2

Cole, M. S., Bruch, H., \& Vogel, B. (2012). Energy at work: A measurement validation and linkage to unit effectiveness. Journal of Organizational Behavior, 33, 445-467. http://dx.doi.org/ 10.1002/job.759

Donaldson, S. I., \& Ko, I. (2010). Positive organizational psychology, behavior, and scholarship: A review of the emerging literature and evidence base. The Journal of Positive Psychology, 5(3), 177-191. http://dx.doi.org/ $10.1080 / 17439761003790930$

Duffy, M. K., Scoot, K. L., Shaw, J. D., Tepper, B. J., \& Aquino, K. (2012). A social context of envy and social undermining. Academy of Management Journal, 55(3), 643-666. http://dx.doi.org/10.5465/amj.2009.0804

Dutton, J. E. (2003). Energize your workplace. How to create and sustain high quality connections at work. San Francisco: Jossey-Bass.

Emmons, R. A. (2003). Acts of gratitude in organizations. In K. S. Cameron, J. E. Dutton, \& R. E. Quinn (Eds.), Positive organizational scholarship: Foundations of a new discipline (pp. 81-93). San Francisco, Berrett-Koehler Publishers.

Emmons, R. A., \& Shelton, C. S. (2002). Gratitude and the science of positive psychology. In C. R. Synder, \& S. J. Lopez (Eds.), Handbook of positive psychology (pp. 459-471). New York: Oxford University Press.

Emmons, R. A., McCullough, M. E., \& Tsang, J. (2003). The assessment of gratitude. In S. J. Lopez, C. R. Synder (Eds.), Positive psychological assessment: A handbook of models and measures. Washington, DC: American Psychological Association. http://dx.doi.org/10.1037/10612-021

Fernet, C., Gagne, M., \& Austin, S. (2010). When does quality of relationships with coworkers predict burnout over time? The moderating role of work motivation. Journal of Organizational Behavior, 31, 1163-1180. http://dx.doi.org/10.1002/job.673

Fineman, S. (2006). On being positive: Concerns and counterpoints. Academy of Management Review, 31(2), 270-291. http://dx.doi.org/10.5465/AMR.2006.20208680

Fitzgerald, P. (1998). Gratitude and Justice. Ethics, 109(1), 119-153. http://dx.doi.org/ 10.1086/233876

Fredrickson, B. L. (2001). The role of positive emotions in positive psychology: The broaden and build theory of $\begin{array}{llll}\text { positive emotions. } & \text { American }\end{array}$ http://dx.doi.org/10.1037//00O3-066X.56.3.218

Fredrickson, B. L. (2004). Gratitude, like other positive emotions, broadens and builds. In R. A. Emmons, \& M. E. McCullough (Eds.), Psychology of Gratitude (pp. 144-166). NC: Oxford University Press. http://dx.doi.org/10.1093/acprof:oso/9780195150100.003.0008

Froh, J. J., Emmons, R. A., Huebner, E. S., Fan, J., Bono, G., \& Watkins, P. (2011). Measuring gratitude in youth: Assessing the psychometric properties of adult gratitude scales in children and adolescents. Psychological Assessment, 23(2), 311-324. http://dx.doi.org/10.1037/a0021590

Gable, S. L., \& Haidt, J. (2005). What (and why) is positive psychology? Review of General Psychology, 9(2), 103-110. http://dx.doi.org/10.1037/1089-2680.9.2.103

Gilson, L. L., \& Goldberg, C. B. (2015). Editors' comment: So, what is a conceptual paper? Group and Organization Management, 40(2), 127-130. http://dx.doi.org/10.1177/1059601115576425

Goetzel, R. Z., Guindon, A. M., Turshen, I. J., \& Ozminkowski, R. J. (2001). Health and productivity management: Establishing key performance measures, benchmarks and best practices. Journal of Occupational Environment 43, 10-17. http://dx.doi.org/10.1097/00043764-200101000-00003

Grant A. M., Dutton J. E., \& Rosso B. D. (2008). Giving commitment: Employee support programs and the prosocial sensemaking process. Academy of Management Journal, 51(5), 898-918. http://dx.doi.org/10.5465/AMJ.2008.34789652

Grant, A., M., \& Wrzesniewski, A. (2010). I won't let you down... or will I? Core self-evaluations, other-orientation, anticipated guilt and gratitude and job performance. Journal of Applied Psychology, 95(1), 108-121. http://dx.doi.org/10.1037/a0017935 946

Hu, X., \& Kaplan, S. (2015). Is "feeling good" good enough? Differentiating discrete positive emotions at work. 
Journal of Organizational Behavior, 36, 39-58. http://dx.doi.org/10.1002/job.1941

Huy, Q. N. (2002). Emotions in strategic organizations: Opportunities for impactful research. Faculty \& Research Working Paper, INSEAD.

Khan, A. K., Quratulain, S., \& Bell, C. M. (2014). Episodic envy and counterproductive work behaviors: Is more justice always good? Journal of Organizational Behavior, 35(1), 218-144. http://dx.doi.org/10.1002/job.1864

Kluemper, D. H., Little, L. M., \& DeGroot, T. (2009). State or trait: Effects of state optimism on job related outcomes. Journal of Organizational Behavior, 30, 209-231. http://dx.doi.org/10.1002/job.591

Lambert, N. M., Graham, S. M., \& Finchman, F. D. (2009). A prototype analysis of gratitude: Varieties of gratitude experiences. Personality and Social Psychology Bulletin, 35, 1193-1207. http://dx.doi.org/10.1177/0146167209338071

Lazarus, R. S., \& Lazarus, B. N. (1994). Passion and reason: Making sense of our emotions. New York: Oxford University Press.

Lindebaum, D., \& Jordan, P. J. (2012). Positive emotions, negative emotions, or utility of discrete emotions? Journal of Organizational Behavior, 33, 1027-1030. http://dx.doi.org/10.1002/job.1819

Luthans, F. (2002). Positive organizational behavior: Developing and managing psychological strengths. Academy of Management Executive, 16(1), 57-72. http://dx.doi.org/10.5465/AME.2002.6640181

Luthans, F., \& Jensen, S. M. (2002). Hope: A new positive strengths for human resource development. Human Resource Development Review, 1(3), 304-322. http://dx.doi.org/10.1177/1534484302013003

McCullough, M. E., Klipatrick, S. D., Emmons, R. A., \& Larson, D. B. (2001). Is gratitude a moral affect? Psychological Bulletin, 127(2), 249-266. http://dx.doi.org/10.1037//0033-2909.127.2.249

McCullough, M. E., Emmons, R. A., \& Tsang, J. A. (2002). The grateful disposition: A conceptual and empirical topography. Journal of Personality and Social Psychology, 82(1), 112-127. http://dx.doi.org/10.1037//0022-3514.82.1.112

Muller, A. R., Pfarrer, M., \& Little, L. M. (2014). A theory of collective empathy in corporate philanthropy decisions. Academy of Management Review, 39(1), 1-21. http://dx.doi.org/10.5465/amr.2012.0031

Palmatier, R. W., Jarvis, C. B., Bechkoff, J. R., \& Kardes, F. R. (2009). The role of customer gratitude in relationship marketing. Journal of Marketing, 73, 1-18. http://dx.doi.org/10.1509/jmkg.73.5.1

Park, N., \& Peterson, C. M. (2003). Virtues and organizations. In K. S. Cameron, J. E. Dutton, \& R. E. Quinn (Eds.), Positive organizational scholarship: Foundations of a new discipline (pp. 33-47). San Francisco: Berrett-Koehler Publishers.

Podaskoff, N. P., Podaskoff, P. M., Mackenize, S. B., Maynes, T. D., \& Spoelma, T. M. (2014). Consequences of unit-level organizational citizenship behaviors: A review and recommendations for future research. Journal of Organizational Behavior, 35, 87-119. http://dx.doi.org/10.1002/job.1911

Raggins, B. R., \& Dutton, J. E. (2007). Positive relationships at work: An introduction and invitation. In Exploring positive relationships at work (pp. 3-25). New Jersey: Lawrance Erlbaum Associates.

Raggio, R. D., Walz, A. M., Godbole, M. B., \& Folse, J. A. G. (2014). Gratitude in relationship marketing: Theoretical development and directions for future research. European Journal of Marketing, 48(1/2), 2-24. http://dx.doi.org/10.1108/EJM-08-2009-0355

Rego, A., Ribeiro, N., \& Cunha, M. P. (2010). Perceptions of organizational virtuousness and happiness as predictors of organizational citizenship behavior. Journal of Business Ethics, 93, 213-235. http://dx.doi.org/10.1007/s10551-009-0197-7

Rego, A., Ribeiro, N., Cunha, M. P., \& Jesuino, J. C. (2011). How happiness mediates the organizational virtuousness and affective commitment relationship. Journal of Business Research, 64, 524-532. http://dx.doi.org/10.1016/j.jbusres.2010.04.009

Roberts, L. M. (2006). Shifting the lens on organizational life: The added value of positive scholarship. Academy of Management Review, 3(2), 292-305. http://dx.doi.org/10.5465/AMR.2006.20208681

Romani, S., Grappi, S., \& Bagozzi, R. P. (2013). Explaining consumer reactions to corporate social responsibility: The role of gratitude and altruistic values. Journal of Business Ethics, 114, 193-206. http://dx.doi.org/10.1007/s10551-012-1337-z 
Sekerka, L. E., Vacharkulksemsuk, T., \& Fredrickson, B. L. (2012). Positive emotions. broadening and building upward spirals of sustainable enterprise. In K. S. Cameron, \& S. Gretchen (Eds,), The Oxford Handbook of Positive Organizational Scholarship (pp. 168-177). New York: Oxford University Press.

Seligman, M. E. P., \& Csikszentmihalyi, M. (2000). Positive psychology: An introduction. American Psychologist, 55(1), 5-14. http://dx.doi.org/10.1037/003-06X.55.1.5

Shryack, J., Steger, M. F., Krueger, R. F., \& Kallie, C. S. (2010). The structure of virtue: An empirical investigation of the dimensionality of the virtues in action inventory of strengths. Personality and Individual Differences, 48, 714-719. http://dx.doi.org/ 10. 1016/j.paid.2010.01.007

Smith, C. A., \& Ellsworth, P. C. (1985). Patterns of cognitive appraisal in emotion. Journal of Personality and Social Psychology, 48(4), 813-838. http://dx.doi.org/10.1037//0022-3514.48.4.813

Stephens, J. P., Heaphy, E., \& Dutton, J. E. (2012). High quality connections. In K. S. Cameron, \& S. Gretchen (Eds,), The Oxford Handbook of Positive Organizational Scholarship (pp. 385-399). New York: Oxford University Press.

Tai, K., Narayanan, J., \& Mcallister, D. J. (2012). Envy as pain: Rethinking the nature of envy and its implications for employees and organizations. Academy of Management Review, 37(1), 107-129. http://dx.doi.org/10.5465/amr.2009.0484

Tesser, A., Gatewood, R., \& Driver, M. (1968). Some determinants of gratitude. Journal of Personality and Social Psychology, 9(3), 233-236. http://dx.doi.org/10.1037/h0025905

Tsang, J., Schulwitz, A., \& Carlisle, R. D. (2012). An experimental test of the relationship between religion and gratitude. Psychology of Religion and Spirituality, 4(1), 40-55. http://dx.doi.org/10.1037/a0025632

Walumbwa, F. O., Luthans, F., Avey, J. B., \& Oke, A. (2009). Authentically leading groups: The mediating role of collective psychological capital and trust. Journal of Organizational Behavior, 32, 4-24. http://dx.doi.org/10.1002/job.653

Watkins, P. C., Gelder, M., \& Frias, A. (2009). Furthering the science of gratitude. In S. J. Lopez, \& C. R. Synder (Eds.), The Oxford Handbook of Positive Psychology. New York, Oxford University Press. http://dx.doi.org/10.1093/oxfordhb/9780195187243.013.0041

Watkins, P. C., Woodward, K., Stone, T., \& Kolts, R. L. (2003). Gratitude and happiness: Development of a measure of gratitude, and relationships with subjective well-being. Social Behavior and Personality, 31(5), 431-452. http://dx.doi.org/10.2224/sbp.2003.31.5.431

Weiss, H. M., \& Cropanzano, R. (1996). Affective events theory: A critical discussion of the structure, causes and consequences of affective experiences at work. Research in Organizational Behavior, 18, 1-74.

Williams, M. (2012). Perspective taking: Building positive interpersonal connections and trustworthiness one interaction at a time. In K. S. Cameron, \& S. Gretchen (Eds.), The Oxford handbook of positive organizational scholarship (pp. 462-472). New York: Oxford University Press.

Wright, T. A., \& Diamond, W. J. (2006). Getting the pulse of your employees: The use of cardiovascular research in better understanding behavior in organizations. Journal of Organizational Behavior, 27, 395-401. http://dx.doi.org/10.1002/job.374

Wright, T. A., \& Quick, J. C. (2009). The role of positive-based research in building the science of organizational behavior. Journal of Organizational Behavior, 30, 329-336. http://dx.doi.org/10.1002/job.581

\section{Copyrights}

Copyright for this article is retained by the author(s), with first publication rights granted to the journal.

This is an open-access article distributed under the terms and conditions of the Creative Commons Attribution license (http://creativecommons.org/licenses/by/3.0/). 